\title{
INVESTIGATION ON SUITABLE SPAT COLLECTIORS AND CULTURE SITES FOR EDIBLE OYSTER IN THE COAST OF BAY OF BENGAL, BANGLADESH
}

\author{
Jakia Hasan ${ }^{1 *}$, Md. Mozzammel Hoque ${ }^{2}$, Ahmed Fazley Rabbi ${ }^{1}$ \\ Shafiqur Rahman and Md. Zulfikar $\mathrm{Ali}^{3}$ \\ ${ }^{1}$ Marine Fisheries \& Technology Station, Bangladesh Fisheries Research Institute, \\ Cox's Bazar, Bangladesh
}

\begin{abstract}
Potential spat collectors and suitable culture sites were investigated for the development of edible oyster culture from June to December 2019 at three study sites (Moheshkhali, the Jeti of Nuniarchora, and Sonadia) of Cox's Bazar coast of Bangladesh. Four types of collectors such as oyster shell, earthen pot, kortal (windowpane oyster shell) and tiles were investigated. On site sampling of water quality parameters and number of spats on each collector were done at 15days interval following standard methods. Results indicated insignificant difference $(\mathrm{P}>0.05)$ in temperature, salinity, dissolved oxygen and $\mathrm{pH}$, while significant difference $(\mathrm{P}<0.05)$ in total dissolved solids, total suspended solids and Chl-a content of the water among the study locations. However, these parameters were in suitable range for growth and spawning of oyster. Results also indicated spat recruitment was significantly influenced by the types of collectors and study locations with significantly $(\mathrm{P}<0.05)$ higher spat were recruited in Tiles. Tiles were also found to facilitate with an advantage of recycling of this collector. The location in interaction with polluting materials such as total dissolved solids and total suspended solids had a significant effect on spat recruitment rate and therefore, Sonadia was the most suitable location for spat recruitment. This study site can also be used as a suitable location for the development of oyster culture in the cost of Bay of Bengal, Bangladesh based on its environmental characteristics.
\end{abstract}

Key words: Collectors, oyster spat, recruitment, oyster culture, two-way ANOVA, Bay of Bengal

\section{INTRODUCTION}

Oysters are the most important cultured species worldwide for aquaculture production (FAO 2018). Oysters are found to inhabit in coastal waters of temperate, subtropics and topics around the globe (Grabowski et al. 2008). Bangladesh possesses numerous coves, bays and estuaries that have the potential to be developed as a site for oyster culture. Specially, the channel between Sonadia and Moheskhali Islands has a potential farming area of more than 1,500 hectare. Oyster can provide animal protein which is rich in food

\footnotetext{
*Author for corresponding: <jakiabfri@gmail.com>, 2Riverine Station, Bangladesh Fisheries Research Institute, Chandpur, Bangladesh, ${ }^{3}$ Marine Fisheries \& Technology Station, Bangladesh Fisheries Research Institute, Cox's Bazar, Bangladesh, ${ }^{3}$ Research Division, Head quarter, Bangladesh Fisheries Research Institute, Mymensing, Bangladesh

(C2021 Zoological Society of Bangladesh DOI: https://doi.org/10.3329/bjz.v49i2.56262
} 
value. However, the majority of the population of Bangladesh do not take oyster as food due to their traditional believe, but it has the potential to be a major export items like other shellfishes. Therefore, it can provide social and economic wellbeing to the community due to its low capital investment and existing technology. Although, oyster farming does not require high cost and skilled manpower, development of farming system is depended on collection of oyster spats and selection of suitable sites for the introduction of culture system. Therefore, a thorough investigation of the environmental parameters and rate of spat fall on collectors is essential to initiate successful culture practices in commercial scale. The biology of oyster is greatly influenced by the environmental factors in the habitat. Feeding, growth, maturation, spawning and development are greatly influenced by varying environmental factors such as water temperature, salinity, $\mathrm{pH}$, dissolved oxygen, food availability and pollution (Tolley et al. 2005, Fulford et al. 2007). Water transport, feeding, physiology and gonadal maturation of oysters are controlled by the temperature and salinity of the surrounding environment (Dame et al. 2002). Growth and development of oyster at population and individual level was also influenced by the fluctuation of dissolved oxygen of water (Molnar et al. 2008). Not only that, seasonal fluctuation in environmental parameters can influence the biochemical composition of oyster muscle that ultimately reduce the reproductive capability of oyster. A long term monitoring of relevant hydro biological parameters is therefore needed to explore the environmental potential of the region to develop large-scale oyster culture practice. Collection of wild oyster spat is the prerequisite for cultural development of oyster in any area. Successful collection of spats from natural habitats depends on the types and nature of the collectors used (Christo and Cruz 2009). Collectors are structures that are installed in the environment and used for settlement by oyster larvae and other encrusting organisms reported in water (Castilho-Westphal et al. 2015). Several authors have reported the use of different collectors for spat collection, such as transparent PET bottles, green PET bottles, and PVC sheets (Funo et al. 2019); oyster shells, PET bottles, car tires and tiles (Nalesso et al. 2008); and different types of nets (Saucedo et al. 2005). However, none of these collectors yet not been evaluated for spat collection in the coastal area of Bangladesh. Therefore, in the present study, attempts were made to investigate the most effective collectors for oyster spat collection. Furthermore, this study also provided information for the selection of suitable location for oyster farming based on the evaluation of water quality parameters. 


\section{MATERIAL AND METHODS}

The study was conducted for a period of 7 months from June to December 2019. Three potential locations (Fig. 1) were selected by pre survey at the Moheshkhali, Jeti of Nuniarchora, and Sonadia of Cox's Bazar coast of Bangladesh.

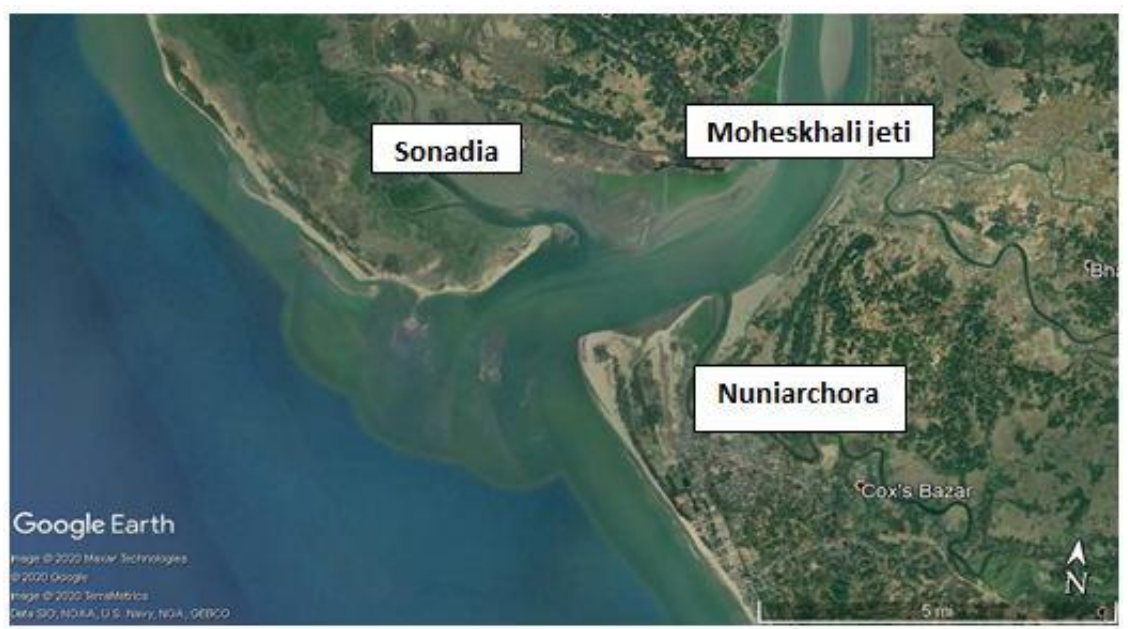

Fig. 1 Locations of the study area.

Water temperature was measured using a Celsius thermometer and water $\mathrm{pH}$ using an electronic $\mathrm{pH}$ meter (Jenwary 3020). Dissolved oxygen (DO) was measured by a portable aquaculture kit (Model FF2, HACH, USA) and salinity with a salinity meter (YSI Multiprobe 556MPS). Total dissolved solids (TDS) and Total solid suspended (TSS) were measured with an EC, TDS tester (Adwa AD31 waterproof EC/TDS Testers) and gravimetric method (APHA, 1995). Concentration of Chl-a was determined by spectrophotometry using the method of Jeffrey and Humphrey (1975).

4 clutch materials such as oyster shell, earthen pot, kortal (windowpane oyster shell) and tiles were used oyster spat collection. 12 cultch materials were placed (each with a distance of $10-12 \mathrm{~cm}$ ) into a $1.5 \mathrm{~m}$ length roof. The roofs were than hanged beneath the Jeti located in the study locations (Fig. 2). Bimonthly, during low tides, the collectors with oyster spat were withdrawn, and replaced with the new one. The number of spat recruited on each collector was counted and calculated per $\mathrm{m}^{2}$ area of each type of collector.

Data on water quality parameters and spat density were analyzed to ensure the normality using the Kolmogorov-Smirnov test and homogeneity of variance using Cochran tests $(\mathrm{P}<0.05)$. One-way analysis of variance (ANOVA) was used to compare the mean values of water quality parameters among the 
study locations. To determine the influence of factors such as collector's type and study locations, Two-way analysis of variance and Duncan multiple range test $(\mathrm{P}<0.05)$ were performed. Finally, the correlation between the density of spats at each of the collectors and water quality parameters were evaluated by Pearson correlation matrix in package ggplot2 in $\mathrm{R}$ statistical program. All the analyses were performed in Statistical Package for Social Science (SPSS) version. 20.

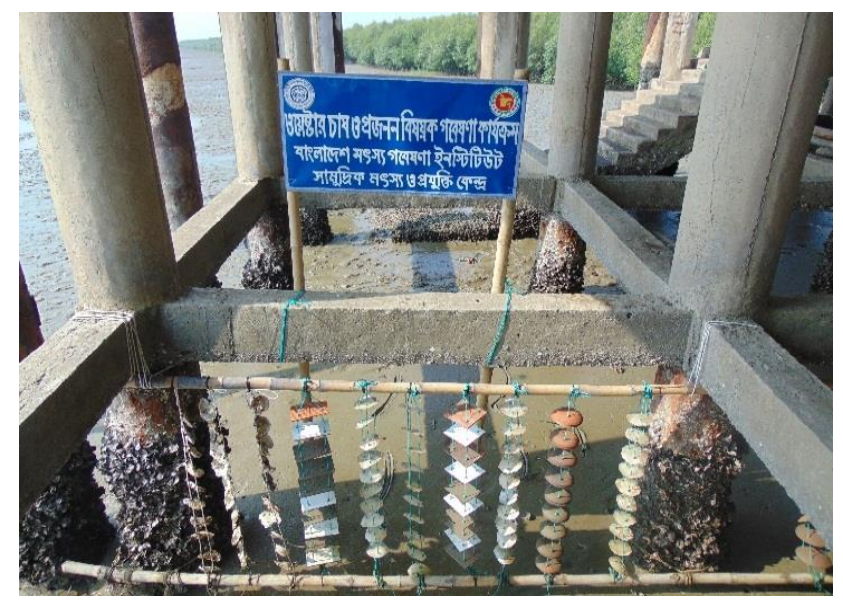

Fig. 2. Installation of clutch materials in the study locations.

\section{RESULTS AND DISCUSSION}

Water quality parameters recorded during the study period are shown in Table 1. No significant difference $(\mathrm{P}>0.05)$ was observed in temperature, salinity, dissolved oxygen and $\mathrm{pH}$ among the study locations. However, these parameters were in suitable range for growth and spawning of oyster. Temperature and salinity are the factors which have great importance on oyster spawning. Water transport, feeding, respiration, gonadal maturation and spawning of oyster are primarily controlled by the temperature of water (Ward et al. 2000).

Therefore, the abundance of oyster species at the same bed is determined by water temperature (Naik and Gowda 2013). Ciliary movement of the gills is declined at below $20.5{ }^{\circ} \mathrm{C}$ and above $32{ }^{\circ} \mathrm{C}$. However, the suitable temperature for maximum ciliary movement of the gills is $24-26{ }^{\circ} \mathrm{C}$ (Galtsoff 1964). During the study period, the study locations had the temperature ranged between $27.35 \pm 0.74$ (Nuniarchora) to $27.67 \pm 0.76{ }^{\circ} \mathrm{C}$ (Sonadia), which was suitable for growth and recruitment of oyster spat according to the findings of Lagarde et al. (2017). Low salinity (below 8ppt) causes physiological changes in oyster that influence them to close their shell and stop filtering (Nalesso et al. 2008, 
Nascimento and Pereira 2004). During the study period, salinity of water ranged between $21.64 \pm 8.32$ (Nuniarchora) to $26.33 \pm 7.64 \mathrm{ppt}$ (Sonadia) which signified the suitability of our study locations for oyster culture. Study conducted by Miranda and Guzenski (1999) and Lemos et al. (1994) also reported best salinity for oyster spat ranged between 25-30 ppt. Concentration of dissolved oxygen in Table 1. Water quality parameters of the studied locations

\begin{tabular}{llllll}
\hline Parameters & Nuniarchora & Moheskhali & Sonadia & $\begin{array}{c}\text { F- } \\
\text { value }\end{array}$ & $\begin{array}{c}\text { P- } \\
\text { value }\end{array}$ \\
\hline Temperature $\left({ }^{\circ} \mathrm{C}\right)$ & $27.35 \pm 0.74^{\mathrm{a}}$ & $27.44 \pm 0.64^{\mathrm{a}}$ & $27.67 \pm 0.76^{\mathrm{a}}$ & 0.163 & 0.853 \\
Salinity $(\mathrm{ppt})$ & $21.64 \pm 8.32^{\mathrm{a}}$ & $24.51 \pm 8.14^{\mathrm{a}}$ & $26.33 \pm 7.64^{\mathrm{a}}$ & 0.260 & 0.779 \\
Dissolved oxygen $(\mathrm{mg} / 1)$ & $6.56 \pm 0.84^{\mathrm{a}}$ & $6.52 \pm 0.52^{\mathrm{a}}$ & $6.99 \pm 0.32^{\mathrm{a}}$ & 0.555 & 0.601 \\
pH & $7.38 \pm 0.34^{\mathrm{a}}$ & $7.68 \pm 0.28^{\mathrm{a}}$ & $7.50 \pm 0.50^{\mathrm{a}}$ & 0.461 & 0.651 \\
Total dissolved solids & $112.33 \pm 12.50^{\mathrm{ab}}$ & $123.67 \pm 12.01^{\mathrm{a}}$ & $95.67 \pm 10.50^{\mathrm{c}}$ & 4.344 & 0.050 \\
$(\mathrm{mg} / \mathrm{l})$ & & & & & \\
Total suspended solids & $328.00 \pm 56.72^{\mathrm{b}}$ & $585.33 \pm 114.76^{\mathrm{a}}$ & $158.00 \pm 51.26^{\mathrm{c}}$ & 21.909 & 0.002 \\
$(\mathrm{mg} / \mathrm{l})$ & $3.77 \pm 0.71^{\mathrm{b}}$ & $1.73 \pm 0.15^{\mathrm{c}}$ & $6.73 \pm 0.75^{\mathrm{a}}$ & 52.798 & 0.000 \\
Chl-a $(\mu \mathrm{g} / \mathrm{l})$ & & & & & \\
\hline
\end{tabular}

water is also important for growth and maturation of oyster (Naik and Gowda 2013). However, oyster can survive in very low concentration of dissolved oxygen (Andrews 1982). Dissolved oxygen concentration of the studied location were varied in a narrow range it was suitable for culture of oyster in that localities. Narrow range of fluctuation in $\mathrm{pH}$ was also recorded during the study period and it was suitable for culture of oyster as reproduction of oyster was reported to be influenced by $\mathrm{pH}$ above 9 (Mathew et al. 2008) and declined pumping ability at $\mathrm{pH}$ below 4.0-6.5 (Madhavan and Nagappan Nayar 1987). During the study period, the mean values of total dissolved solids, total suspended solids and Chla content of the water were varied significantly $(\mathrm{P}<0.05)$ among the study locations. The highest values of total dissolved solids $(123.67 \pm 12.01 \mathrm{mg} / \mathrm{l})$ and total suspended solids (585.33 $\pm 114.76 \mathrm{mg} / 1)$ were recorded at Moheskhali and the lowest at Sonadia station $(95.67 \pm 10.50 \mathrm{mg} / 1$ and $158.00 \pm 51.26 \mathrm{mg} / 1$, respectively). Sonadia had the highest Chl-a content $(6.73 \pm 0.75 \mu \mathrm{g} / 1)$ followed by Moheskhali $(3.77 \pm 0.71 \mu \mathrm{g} / 1)$ and Nuniarchora $(1.73 \pm 0.15 \mu \mathrm{g} / 1)$. One of the factors that tend to inhibit the growth and productivity of an oyster community are sedimentation which are responsible for higher values of total dissolved solids and total suspended solids in aquatic environment. Therefore, the higher values of these two parameters at Moheskhali and Nuniarchora signified their inappropriateness over Sonadia to be selected as a location for oyster culture in the cost of Bay of Bengal. Moheskahli and Nuniarchora were the locations that are heavily disturbed by ship landings and other fisheries activities. On the contrary, Sonadia was free the disturbing factors the other two locations had. 
Nevertheless, Chl-a, that determined the food availability in water was significantly higher at Sonadia compared to Nuniarchora and Moheskhali, which also justified the suitability of Sonadia as a location of oyster spat collection and culture potentiality. Mean density of oyster spats on each studied collectors are shown in Fig. 3. During the study period, oyster spats were found to show different settlement behavior on different collectors, which was similar to the findings of

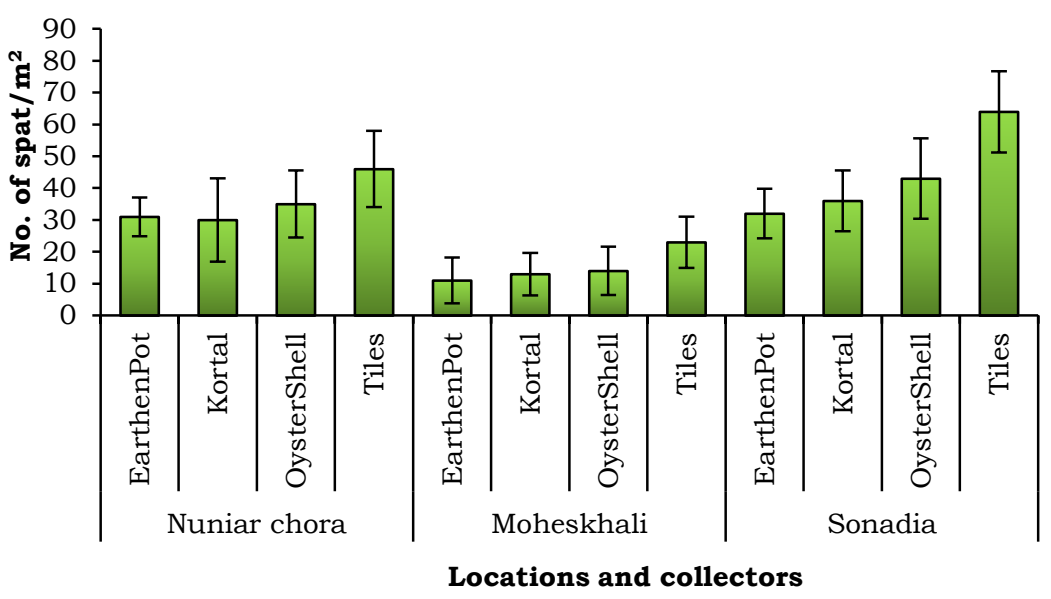

Fig. 3. Mean density of oyster spats at different collectors and locations in the coast of Bay of Bengal Bangladesh

Lee et al. (2012) and Nalesso et al. (2008). Number of spats per $\mathrm{m}^{2}$ of collectors were significantly $(\mathrm{F}=7.425, \mathrm{P}=0.001)$ higher at Tiles $(64,43$ and 24 at Sonadia, Nuniarchora and Moheskhali, respectively) in all the study locations. The number of oyster spats occupied second position in Oyster shell followed by Kortal and Earthen Pot. During the study period, number of oyster spats recruited at each collector also showed extreme spatial heterogeneity among the study locations. In relation to the location, the number of spats was significantly $(\mathrm{F}=26.16, \mathrm{P}=0.000)$ higher at Sonadia, coinciding with the higher concentration of Chl-a, and lower concentrations of Total dissolved solids and total suspended solids. Food availability is an important determinant of oyster spat recruitment (Funo et al. 2019) which was depicted at Sonadia location with higher recruitment of oyster spats and concentration of Chl-a. During the study period, some difficulties were encountered during detachment of oyster spats from oyster shell. Similar observation was also reported by Buitrago and Alvarado (2005) during the study period. The majority of the spats were found 
attached in the lower side of each collector indicating their negative phototrophic behaviour and their tendency to prohibit the exposure of suspended particles. Saucedo et al. (2005) and Buitrago and Alvarado (2005) also reported that direct photoperiod and suspended particles of water influence the recruitment of oyster spats in collectors. During the study period, Tiles was found more durable and cost effective compared to other types of collectors. Most of the oyster shells were unsuitable for use after experimental period. Similar result was also noted for Kortal and Earthen Pot. Numbers of Earthen Pot were found missing after the experimental period. On the other hand, Tiles had the surface area easily favoured for recruiting of oyster spats and recycling of these tiles were possible that reduced the overall cost of the experiment.

Correlation heat map of water quality parameters and density of oyster spats on each collecting clutch is shown in Fig. 4. Significant $(P<0.05)$ negative correlation was observed between Total dissolved solids and total suspended solids of water and the density of oyster spats in oyster shell, kortal, tiles and earthen pot. Chl-a content of the water had significantly $(\mathrm{P}<0.05)$ positive effect on spat fall in oyster shell and tiles. Therefore, food availability together with pollution free environment was favourable for spats recruitment in collectors.

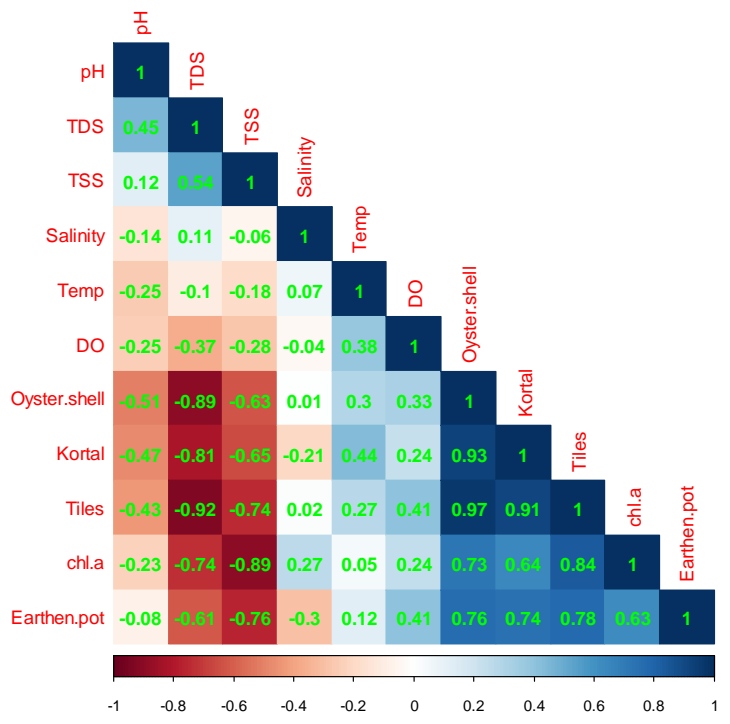

Fig. 4. Correlation heat maps of water quality parameters and spat density in different collectors

\section{CONCLUSION}

The present study revealed that the best location for collecting oyster spats should be equipped with abundant food availability and less pollution in terms 
of total dissolved solids and total suspended solids. Therefore, Sonadia was proved to be the best place for spat collection and might be a suitable location for the development of oyster culture in the cost of Bay of Bengal. Regarding the collectors, all were suitable for spat collection. However, the best choice would be Tiles as the density of oyster spats was higher in Tiles. Besides this, recycling of the Tiles provided an advantage, as the cost relating to the buying of collectors was low.

Acknowledgement: The author wishes to thank the conservation, propagation and culture of mussels and snail in Bangladesh (BFRI) project for funding this research from core research program.

\section{LITERATURE CITED}

ANDREWS, J.D. 1982. Management strategies to control the disease caused by Perkinsus marinus. American Fish. Socie.18: 257-264.

BUITRAGO, E. and ALVARADO, D. 2005. A highly efficient oysters pat collector made with recycled materials. Aquacult. Engng, 33: 63-72.

CASTILHO-WESTPHAL, G.G.,MAGNANI,F.P. and OSTRENSKY,A. 2015. Gonad morphology and reproductive cycle of the mangrove oyster Crassostrea brasiliana (Lamarck, 1819) in the Baia de Guaratuba, Paraná, Brazil. Acta Zool. 96: 99-107.

CHRISTO, S.W. and CRUZ, E. 2009. Recruitment of oysters and Barnacles (cirripedia) in na artificial channel in Pontal do Sul, Pontaldo Paraná, Paraná. Publication UEPG Biol. Healt. Sci.15(2): 4348.

DAME, R.D., BUSHEK, D., ALLEN, D., KOEPFLER, E., LEWITUS, A. and EDWARDS. 2002. Ecosystem response to bivalve density reduction: management implications. Aqua. Ecol.36: 5165.

FAO. 2018. Fisheries \& aquaculture, global statistical collection; http://www.fao.org/fishery/statistics/en

FULLFORD, R.S., BREITBURG, D.L., NEWELL, R.I.E., KEMP, W.M. and LUCKENBACH, M.W. 2007. Effects of oyster population restoration strategies on phytoplankton biomass in Chesapeake Bay: a flexible modeling approach. Mar. Ecol. Prog. Seri. 336: 43-61.

FUNO, I.C., da SILVA, A., ANTONIO, Í.G., MARINHO, Y.F., MONTELES, J.S. LOPES, R.G.P.S. and GÁLVEZ, A.O. 2019. Recruitment of oyster in artificial collectors on the Amazon macro tidal mangrove coast. Ciência. Rural. 49(3): 1-12.

GALTSOFF, P.S. 1964. The American oyster Crassostrea virginica.U.S. Fish and Wildlife Serv. Fish.Bull. 64: 1-48.

GRABOWSKI, J.H., HUGHES, A.R. and KIMBRO, D.L. 2008. Habitat complexity influences cascading effects of multiple predators. Ecol. 89: 3413-3422. 
JEFFREY, S. W. and HUMPHREY, G. F. 1975. New spectrophotometric equations for determining chlorophylls a, b, c1 and c2 in higher plants, algae and natural phytoplankton. Biochem. Physiol. Pfl. 167: 191-194.

LAGARDE, F., ROQUE d'ORBCASTEL, E., UBERTINI, M., MORTREUX, S., BERNARD, I., FIANDRINO, A., CHIANTElLA, C., BEC, B., ROQUES, C., BONNET, D., MIRON, G., RICHARD, M., POUVREAU, S. and LETT C. 2017. Recruitment of the Pacific oyster Crassostrea gigas in a shellfish-exploited Mediterranean lagoon: discovery, driving factors and a favorable environmental window. Mar. Ecol. Prog. Ser. 578: 1-17.

LEE, K.M. KRASSOI,F.R. and BISHOP,M.J. 2012. Effects of tidal elevation and substrate type on settlement and post settlement mortality of the Sydney rock oyster, Saccostrea glomerata, in a mangrove forest and on a rocky shore. J. Shellfish Res. 31(4): 1043-1050.

LEMOS, M.B.N., NASCIMENTO, I.A., ARAÚJO, M.M.S., PEREIRA, S.A., BAHIA, I. and SMITH, D.H. 1994. The combined effects of salinity, temperature, antibiotic and aeration on larval growth and survival of the mangrove oyster, Crassostrea rhizophorae. J. Shellfish Res.13: 187-192.

MAHADEVAN, S. and NAGAPPANN AYAR, K. 1987. Ecology of oyster beds. Pub.In CMFRI Bulletin.38: $7-13$.

MATHEW, C.K. 2008. Introduction of non-native oysters: Ecological effects and restoration implications. Annu. Rev.Ecol.Evol. S.36: 643-689.

MIRANDA, M.B.B. and GUZENSKI, J. 1999. Cultivo larval da ostradomangue, Crassostrea rhizophorae (Guilding, 1828), emdiferentescondições de temperatura, salinidadeedensidade. Arq. Ciên. Mar.Fortaleza. 32: 73-84.

MOLNAR, J.L., GAMBOA, R.L., REVENGA, C. and SPALDING, M.D. 2008. Assessing the global threat of invasive species to marine biodiversity. Frontiers Ecol. Environ. 6: 485-492.

NAIK, G.M. and GOWDA, G. 2013. Influence of environmental factors on oysters: A Review. Int. J. Adv. Sci. Tech. Res. 2(3): 341-354.

NALESSO, R.C., PARESQUE, K., PIUMBINI, P.P., TONINI, J.F.R., ALMEIDA, L.G. and

NASCIMENTO, I.A. and PEREIRA, S.A. 2004.Cultivo da ostrademangue Crassostrea rhizophorae (Guilding 1828). In: POLI, C. R.et al. (Eds.). Aqüicult. Florianópolis: Multitarefa Editora. 267288.

NÍCKEL, V.M. 2008. Oyster spat recruitment in Espírito Santo State, Brazil, usingrecycled materials. Brazilian J. Ocean. 56(4): 281-288.

SAUCEDO, P.E., BERVERA-LEON, H., MONTEFORTE, M., SOUTHGATE, P.C. and MONSALVO-SP

ENCER, P. 2005. Factors influencing recruitment of hatchery reared pearl oyster (Pinctada mazatlanica; Hanley 1856) spat. J. Shellfish Res. 24(1): 215-219.

TOLLY, S.G. and VOLETY, A.K. 2005. The role of oysters in habitat use of oyster reefs by resident fishes and decapods crustaceans. J. Shellfish. Dis. 24: 1007-1012.

WARD, R.D., ENGLISH, L.J., McGOLDRICK, D.J., MAGUIRE, G.B., NELL, J.A. and THOMPSON, P.A. 2000. Genetic improvement of the Pacific oyster Crassostrea gigasin Australia. Aquacult. Res.31: 35-44.

(Manuscript received on 10 April, 2021 revised on 10 June, 2021) 